\title{
Research on the Confirmation of Rural Land Rights from the Perspective of Urbanization
}

\author{
Tang Genli \\ China West Normal University \\ Nanchong, China \\ (15651792206@163.com)
}

\author{
Zhao Pengcheng \\ China West Normal University \\ Nanchong, China \\ (zpc996@163.com)
}

\begin{abstract}
This paper tries to put forward pertinence suggestions and feasibility countermeasures for the problems of the confirmation of rural land rights in the process of urbanization. Through field research, literature review and case analysis, the paper found some issues, such as: the confirmation of rural land rights lacks manpower and talents; the higher degree of urbanization, the more disputes of land ownership; the confirmation of rural land rights pulls out the rural marginal man. The paper puts forward four suggestions, such as: Promoting the mechanism of return of talents and the mechanism of integration of urban and rural development; enhancing the capability of grass-roots government in public services and strengthening the propaganda service; Supporting the villagers' autonomy; Governing nail households.
\end{abstract}

Keywords—rural land rights confirmation; urbanization; disputes of land ownership; suggestions and solutions

\section{INTRODUCTION}

There is almost no research on "rural land rights confirmation" in the west. But this paper is to comb some research about foreign land, in order to understand the status of foreign rural land, learn some experience from them and break through the current plight of rural land reform and agricultural modernization in China. The land rights of Britain are mainly different forms of land tenure and it tends to ensure that the renter continue to have the right of using land [1]. In the United States, the government continuously defines and perfects various relationships of rural land from the legal aspect [2]. In Russia, the government established the privatization of property rights of rural land by laws and then promoted the reform of property rights of rural land [3].

The rural land rights confirmation has been the attention of Chinese academia. Studies mainly divided into three categories: First, analyzing and combing the history of land rights confirmation, involving the significance, principle, scheme of rural land rights confirmation [4]. Second, the research on problems, causes and countermeasures of rural land rights confirmation. The studies on problems are more about the disputes of land ownership [5]. Third, the research on the leaders in the rural land reform [6]. But the studies about rural land rights confirmation from the perspective of urbanization are limited, and these research focus on the

This essay is an interim achievement of The College Students' Innovative Entrepreneurial Training Program of Sichuan Province in 2015 entitled

"The investigation of food security in the rural areas of western China" (Licensed No. 201510638062), and The Twelfth Five-Year Social Science Planning Topics of Nanchong in 2015 entitled "Research on the Solutions to the Disputes of Land Ownership of Confirmation of Rural Land Rights under the Background of Rural Urbanization" (Licensed No.

NC2015B009). development of urbanization and the importance of land rights confirmation to the urbanization [7].

\section{The Problem of Rural Land \\ RightS CONFORMATION IN THE PROCESS OF URBANIZATION}

\section{A. Rural land rights confirmation lacks manpower and talents in the process of urbanization}

In the process of urbanization, the development of the city is like a giant magnetic field, attracting all kinds of resources. In terms of human resources, rural middle-aged labor for life work in the city, making contributions to urbanization; the college graduates don't want to return to the countryside-they want to work in cities, although they are from rural areas. These lead to the hollowing out of rural population and brain drain in the countryside. Therefore, rural land rights confirmation lacks professional staff, and there is no hard core to cooperate with the work of land rights confirmation in the village.

\section{B. Rural land rights confirmation triggers social conflicts in the process of urbanization}

The disputes of land rights confirmation tend to occur in the area where the urbanization level is higher. Take Panshi town, Dazhou city as an example, land rights confirmation of Shuang village is fairly smoothly, because it isn't in the key area of the city's construction plan and there is no investment projects in this village. On the contrary, the disputes of land rights confirmation are relatively more in the Wang village, because it is in the key area of the city's construction plan.

1) The contradictions between farmers and grass-roots government cadres

The rural land rights confirmation exist the phenomenon of charging fees. However, the government and company don't give farmers results and certificates after confirmation. The farmers think they are purely to take their money. The policies aren't interpreted to farmers in detail, and the results of rights confirmation aren't timely feedback, which trigger a wide sense of distrust in the grass-roots government officials and rural cadres. The grass-roots government and cadres don't pay enough attention to these phenomenon and they don't take 
proper approaches to deal with rural land disputes, which cause the peasant petition.

2) Disputes of land ownership between farmers and farmers

The government will expropriate the rural land for building public infrastructure in the process of urbanization, involving the farmers' residential land and the fields. However, building public foundation construction will not expropriate all families' land in the village. This produces contradictions and disputes between villagers whose land isn't expropriated and villagers whose land is expropriated, especially about the compensation scheme.

3) Disputes of land ownership among the members of family

The advancement of urbanization makes people regard the interests as more important things, so there are disputes of land ownership even within the family. No matter who owns the house and land, all the family members can live in the house and farm the land in the past. However, under the development of urbanization, people focus on the monetary compensation rather than affection. There are several disputes of land ownership among members of the family in Wang village, which typically are the disputes of house ownership between adopted son and uncles.

\section{The emergence of nail households}

Facing with the interests of urbanization, many villagers' behavior is blind, pursuing their own interests beyond reason and jurisprudence. Therefore, the villagers stuck with his unreasonable interests without taking the many years local friendship and the majesty of the law into account. Such people are gradually emerging in the process of rural land rights confirmation under the background of urbanization.

\section{THE RELATIONSHIP OF URBANIZATION AND THE RURAL LAND RIGHTS CONFIRMATION}

The most important carrier of urbanization is land. The rural land rights confirmation is a foundational engineering and a prerequisite for the advancement of urbanization. Rural land rights confirmation can better ensure realize the local urbanization of farmers, rural urbanization; the accelerated development of rural urbanization can promote the work of rural land rights confirmation and clear rural land property rights as soon as possible.

Most of the villagers will be welcome to land rights confirmation, thinking land rights confirmation is significant in a remote village whose urbanization level is not high. These won't be too much questioning and controversy in the process of land rights confirmation under the simple background.

However, it is much easier to produce disputes in suburban areas where the economic development is higher and the development of urbanization is rapid, especially involved provincial and municipal construction plan. The farmers are aware of the value and benefit of their land, and they compete for the size of land area and the ownership. It is inevitably to produce disputes in these areas .Therefore, the level of urbanization has become important factors to influence the confirmation of rural land rights.

\section{The ReAsons For the Problems of RURAL LAND RIGHTS CONFIRMATION IN THE PROCESS OF URBANIZATION}

\section{A. Human nature - the drive of the economic interests}

In the countryside, the land is the most basic safeguard for farmers. In the face of economic benefits brought by the rapid development of urbanization, every villager has the psychology of becoming the "nouveau riche" by house demolition and land expropriation. Even if they haven't immediately become a "lucky", now every mile of land in the competition for success is the guarantee of the future based on the consideration of appreciation in the future.

\section{B. Incomplete propaganda makes farmers misunderstand the policy}

Some farmers understand some policies of land rights confirmation in other provinces that they once worked. They put forward why the policies of local land rights confirmation are different from other provinces', thus they think the local policy is false. This is because our policies aren't propagandized in place and understood completely by farmers.

\section{The public services of rural community are seriously lagging behind}

Though some things are identified as public goods in the urban, some haven't the nature of public goods in the countryside, so farmers have more expenditure of public services to bear8. If the rural social insurance and medical security system is complete, the villagers wouldn't have the burden for this spending. In addition, the inputs of construction and maintenance of public facilities are also imperfect. The lack of public products and public services intensify the conflicts in the countryside.

\section{Laws are being challenged, the governments compromise to people}

The most prominent performance is the disputes of land ownership among the members of family. The adopted son and uncles for adoptive father's house has gone to court, and the court also has ruled in the ownership of the house. Then uncles appealed to the intermediate court, but it was still the original judgment. However he still disobeyed the court, continuing to cause disputes. The laws are being challenged. Whether people's interest demands are in line with the policy and law, this needs the government to deal with.

\section{The Solution to the Problems of RURAL LAND RIGHTS CONFIRMATION IN THE PROCESS OF URBANIZATION}

\section{A. Improving the mechanism of brain gain and the mechanism of integration of urban and rural development}

Improving the mechanism of brain gain between urban and rural areas, increasing the financial inputs in rural human 
capital and realizing the local urbanization of farmers can keep human resources in the countryside. At the same time, medical insurance and pension security are urban residents' living allowances. However, land is the only guarantee of farmers. Realizing the integration of urban and rural development, focusing on the development of rural economy, increasing farmers' non-agricultural income and giving farmers more property rights are fundamental ways to reduce farmers' disputes.

\section{B. Optimizing the functions of the grass-roots government, strengthening the policy propaganda of rural land rights confirmation}

Most of the township governments are pleased to see the rapid development of urbanization in order to the performance evaluation. Some actions are adverse to protect the land rights and interests of farmers. To redefine the basic functions of the government, correctly handle the relationships between government, market and society, realize the transformation of basic functions of the government and emphasis on social management and public service functions. Policy service is one of the main services that grass-roots governments supply for the rural. Therefore, the governments should strengthen the land policy propaganda deeply and in detail through various channels.

\section{The villagers' autonomy: playing the role of the village committee and cadres in the mediation}

The work of rural land rights confirmation must depends on the rural agents .Village organizations and cadres must play their roles of mediation in the disputes of land ownership. They deal with farmers every day, understanding the villagers and have strong emotions with villagers, so they master the solutions to the contradictions. If there are no these agents, the disputes of land ownership will be more, because land rights confirmation involves the economic interests of the farmers, especially under the background of urbanization.

\section{Governing nail households}

The first land rights confirmation should be a policy issue related to the social stability, an effective method to resolve the contradictions among the people. The second is the administrative problems. Mediation is useless for the nail households, such as: "cunning persons", "slippery fellows" and "rogues", so we can "shelve disputes". Let both the sides of the disputes mediate themselves. If they come to an agreement, they will start the next step. In this way, both sides will realize that continued controversial state isn't good for them, so it is advantageous to handle the disputes.

\section{CONCLUSION}

This article describes the problems of rural land rights confirmation, such as: lacking manpower and talents, the more disputes of land ownership and the emergence of marginalized people under the background of urbanization. It also explores the relationship between urbanization and land rights confirmation and deeply analyses the social impacts generated by the relationship. Under the background of urbanization, we find that when we deal with the affairs involved in farmers' vital interests, we must enable the villagers' autonomy, strengthen the function of grass-roots government in public services and improve the mechanism of integration of urban and rural development. Moreover, democracy and "autocracy" are inseparable, governing rural nail households strictly in accordance with the law. Only then, can we accomplish the project of rural land rights confirmation and comprehensively promote the healthy development of a new socialist countryside.

\section{ACKNOWLEDGMENT}

Heartfelt thanks to great guidance and help of my tutor professor Zhao Pengcheng. Heartfelt thanks to parents' selfless dedication to me. Finally, Heartfelt thanks to the organization and personnel of the conference and each reviewing teacher, scholar and expert of the paper!

\section{REFERENCES}

[1] Shen Han, "History of the British Land System," Shanghai: Xuelin Publishing House, 2005, pp.2-3,327-328. (In Chinese)

[2] Lin Muxuan, "American Land Management System and its Enlightenment," Land \& Resources Herald, 2011, (Z1), pp.68-71. (In Chinese)

[3] Zvi Lerma, Natalya Shagaida, and Zhang di, "Land Policies and Agriculture Land Markets in Russia," Land and Resources Information, 2007, (3), pp.16-19. (In Chinese)

[4] Yu Jianrong and Shi Fengyou, "Several Important Problems about the Current Rural Land Rights Confirmation in Chinese," Southeast Academic Research, 2012, (4), pp.4-11.(In Chinese)

[5] Yu Lina, "The Treatments of Disputes of Collective Land Ownership," China Land, 2010, (6), pp.36-37. (In Chinese)

[6] Cai Ruilin, Chen Wanming and Ye Lin, "The Position and Function of Autonomous Grass-roots Organizations in Advancing Confirmation of Rural Land Right," Reform of Economic System, 2015, (4), pp.4-11. (In Chinese)

[7] Liang Shuang, "Issue on Rural Land Right Verification under the Background of New-type Urbanization," Journal of Shanxi Agricultural Sciences, 2015, 43(10), pp.1359-1362. (In Chinese)

[8] Wang Liwen and Yang Bing, "The Problems of Mechanism of Grassroots Governance in the New Urbanization," South China Rural Area, 2014, (12), pp.12-15. (In Chinese) 